\title{
Laporan Kasus Berbasis Bukti \\ Pemberian Lipid Parenteral secara Dini dan Agresif pada Bayi Prematur: Hubungannya dengan Kejadian Sepsis
}

\author{
Angelina, Rinawati Rohsiswatmo \\ Departemen Ilmu Kesehatan Anak Fakultas Kedokteran Universitas Indonesia/Rumah Sakit Cipto Mangunkusumo, Jakarta
}

Latar belakang. Pemberian lipid parenteral secara dini dan agresif sering tidak optimal karena dikhawatirkan terjadinya sepsis. Hubungan antara pemberian lipid parenteral dengan kejadian sepsis masih kontroversial.

Tujuan. Menilai keamanan dan efikasi pemberian lipid parenteral secara dini dan agresif dalam hal hubungannya dengan kejadian sepsis pada bayi prematur melalui telaah sajian kasus berbasis bukti.

Metode. Menelusuri pustaka secara online dengan menggunakan instrumen pencari Pubmed, Cochrane, dan Highwire. Kata kunci yang digunakan adalah "lipid", "fat", "parenteral", preterm", "premature", "low birth weight". Batasan yang digunakan adalah studi berupa uji klinis, telaah sistematik, atau meta analisis, berbahasa Inggris, dilakukan pada manusia, publikasi dalam 10 tahun terakhir. Hasil. Meta-analisis oleh Vlaardingerbroek dkk menunjukkan pemberian lipid parenteral secara dini pada bayi prematur dengan BBLSR tidak meningkatkan insidens sepsis (risk ratio 0,88; IK95\% 0,72-1,08; p=0,22). Meta-analisis oleh Simmer dan Rao tidak dapat dilakukan karena definisi sepsis yang tidak seragam, walaupun masing-masing penelitian tidak menunjukkan peningkatan kejadian sepsis pada kelompok yang mendapat lipid parenteral kurang dan sama dengan lima hari setelah lahir. Uji acak terkontrol oleh Ibrahim dkk dan Vlaardingerbroek dkk menunjukkan pemberian lipid parenteral 2-3 gram/kgBB/hari segera setelah lahir tidak meningkatkan kejadian sepsis yang bermakna secara statistik.

Kesimpulan. Pemberian lipid parenteral secara dini dan agresif pada bayi prematur tidak terbukti berhubungan dengan kejadian sepsis neonatorum. Sari Pediatri 2016;18(4):332-8

Kata kunci: prematur, lipid parenteral, sepsis

\section{Early and Aggresive Parenteral Lipid Administration for Premature Babies: Its Association with Sepsis}

Angelina, Rinawati Rohsiswatmo

Background. Early and aggresive parenteral lipid is often not optimal because of sepsis complication. However, the relationship between parenteral lipid administration and sepsis remains controversial.

Objective. To evaluate the safety and efficacy of early and aggresive parenteral lipid in context of sepsis incidence in premature babies, by evidence-based case study presentation.

Methods. Online browsing using Pubmed, Cochrane, and Highwire. The key words are "lipid", "fat", "parenteral" preterm "," premature "," low birth weight ". Inclusion criteria are clinical study, systematic review, or meta-analysis written in English, conducted in humans, publish in the last 10 years.

Result. Meta-analysis by Vlaardingerbroek et al showed that early and aggresive parenteral lipid for very low birth weight premature babies did not increase the incidence of sepsis (risk ratio 0.88; CI 95\% 0.72-1.08; $\mathrm{p}=0.22$ ). Meta-analysis by Simmer and Rao could not be conducted because of varying definition of sepsis, but every study showed that there was no increased incidence of sepsis in group receiving parenteral lipid within five days after birth. Randomized controlled trial by Ibrahim et al and Vlaardingerbroek et al showed that administration of 2-3 gram $/ \mathrm{kgBW} /$ day parenteral lipid soon after birth did not increased sepsis incidence statistically significant. Conclusion. Administration of early and aggresive parenteral lipid for premature babies was not proven to be associated with neonatal sepsis incidence. Sari Pediatri 2016;18(4):332-8

Keywords: premature, parenteral lipid, sepsis

Alamat korespondensi: Dr. Angelina Arifin, DR. Dr. Rinawati Rohsiswatmo, SpA(K). Departemen Ilmu Kesehatan Anak Fakultas Kedokteran

Universitas Indonesia/Rumah Sakit Cipto Mangunkusumo, Jakarta. Email: angelina.noe@gmail.com; rinarohsis@gmail.com 
Angelina dkk: Pemberian lipid parenteral secara dini dan agresif pada bayi prematur: hubungannya dengan kejadian sepsis

$\mathrm{P}$ emberian nutrisi yang adekuat merupakan salah satu aspek penting dalam tata laksana bayi prematur. Pemberian nutrisi yang tidak adekuat pada awal kehidupan berakibat gagal tumbuh, gangguan perkembangan, serta gangguan imunitas sehingga dapat meningkatkan angka morbiditas dan mortalitas. ${ }^{1-3}$ Data penelitian multisenter di Amerika Utara pada tahun 2000-2013 menunjukkan 50,3\% subjek dengan berat lahir 5011500 gram di perawatan intensif neonatus mengalami gagal tumbuh, dan $27,5 \%$ di antaranya mengalami gagal tumbuh yang berat. ${ }^{4}$

Imaturitas saluran cerna, terjadinya enterokolitis nekrotikans (EKN), dan gangguan metabolik menjadi dasar pemberian nutrisi secara parenteral sebagai pilihan utama pada fase awal kehidupan bayi prematur. ${ }^{5,6}$ Pemberian nutrisi parenteral dini dan agresif telah menjadi kebijakan pada beberapa tempat perawatan intensif neonatus. Lipid merupakan salah satu komponen utama nutrisi parenteral yang mengandung sumber energi tinggi dan asam lemak esensial. Pemberian lipid parenteral seringkali tidak optimal karena ketakutan terhadap kemungkinan terjadinya efek samping, seperti gangguan oksigenasi, peningkatan kejadian displasia bronkopulmoner, pelepasan ikatan bilirubin dan albumin, tombositopenia, serta eksaserbasi terjadinya sepsis. ${ }^{7-10}$ Sepsis neonatorum merupakan masalah besar di negara berkembang seperti Indonesia karena menyebabkan angka kesakitan dan kematian yang tinggi, biaya tata laksana yang mahal, serta sulitnya penegakan diagnosis. ${ }^{11,12}$

Hubungan antara pemberian lipid parenteral dengan kejadian sepsis masih kontroversial, data penelitian yang ada saat ini tidak konsisten menunjukkan hubungan tersebut. Sajian kasus berbasis bukti ini bertujuan untuk menilai keamanan dan efikasi pemberian lipid parenteral secara dini dan agresif dalam hal hubungannya dengan kejadian sepsis pada bayi prematur.

\section{Ilustrasi Kasus}

Seorang bayi lelaki usia gestasi 28 minggu dengan berat lahir 1100 gram, lahir melalui bedah Kaisar emergensi atas indikasi kontraksi dan pembukaan hampir lengkap pada kehamilan prematur. Tidak didapatkan bukti yang jelas mengenai risiko infeksi pada ibu selama masa kehamilan. Saat bayi dilahirkan tidak terdapat usaha napas sehingga diberikan ventilasi tekanan positif dan diintubasi, oksigen diberikan dengan fraksi 21\%-30\% dan tekanan 12/5 mmHg. Bayi diberikan surfaktan 4 mililiter ( $\mathrm{ml})$ per kilogram berat badan $(\mathrm{kgBB})$ satu kali dan dilakukan ekstubasi saat berusia 1 jam.

Pada pemeriksaan fisis tidak tampak kelainan pada bayi. Pasien tidak diberikan minum untuk sementara waktu dan dilakukan pemasangan akses vena sentral untuk mendukung pemberian nutrisi parenteral. Total cairan diberikan $80 \mathrm{ml} / \mathrm{kgBB} /$ hari dengan asam amino 2,5 gram $/ \mathrm{kgBB} /$ hari, lipid $1 \mathrm{gram} / \mathrm{kgBB} / \mathrm{hari}$, dan glukosa dengan glucose infusion rate (GIR) $5-7 \mathrm{mg} /$ $\mathrm{kg} /$ menit. Terapi medikamentosa diberikan adalah antibiotik lini pertama (ampisilin dan gentamisin), aminofilin, dan nystatin oral yang diberikan secara oles pada mukosa mulut.

Saat usia 8 jam pasien mulai diberikan priming menggunakan air susu ibu (ASI). Diet dinaikkan secara bertahap $10 \mathrm{ml} / \mathrm{kg}$ setiap 8 jam dengan total kenaikan $30 \mathrm{ml} / \mathrm{kg} / \mathrm{hari}$. Pada usia 6 hari diet enteral sudah mencapai $120 \mathrm{ml} / \mathrm{kgBB} /$ hari sehingga nutrisi parenteral dihentikan. Bantuan napas non invasif pada pasien diturunkan secara bertahap sesuai dengan klinis, penurunan tidak dapat dilakukan dengan cepat karena terdapat apnu prematuritas berulang.

Masalah apnu berulang pada pasien tidak membaik sehingga pasien dilakukan re-intubasi dua kali selama perawatan, yaitu saat usia 8 hari dan 19 hari. Pada saat kondisi klinis pasien memburuk kembali minum tidak diberikan dan diberikan nutrisi parenteral total. Nutrisi enteral diberikan secara bertahap sesuai dengan kemampuan pasien. Pada usia 19 hari, yaitu ketika pasien dilakukan reintubasi kedua kalinya, pemberian lipid parenteral ditunda selama tiga hari karena klinis infeksi yang berat dan tidak stabil, terdapat takikardia, asidosis metabolik berulang, dan anemia. Nutrisi parenteral kemudian diberikan kembali secara agresif setelah pasien stabil dan pemeriksaan kadar trigliserida dalam batas normal. Total cairan diberikan $160 \mathrm{ml} /$ $\mathrm{kgBB} / \mathrm{hari}$ dengan asam amino 4 gram $/ \mathrm{kgBB} / \mathrm{hari}$, lipid 3 gram $/ \mathrm{kgBB} /$ hari, dan glukosa dengan GIR 12 .

Pemeriksaan marker infeksi ulangan dilakukan setiap kondisi klinis pasien memburuk. Pemeriksaan ulang marker infeksi memburuk sehingga antibiotik diganti menjadi piperasilin tazobaktam kemudian dilanjutkan dengan cefepime. Pemeriksaan kultur darah terakhir didapatkan Staphylococcus epidermidis dan pada pewarnaan gram dari sputum didapatkan banyak kuman gram negatif. Kesan konsultan 
mikrobiologi bahwa hasil kultur darah lebih sesuai dengan kontaminasi kulit dan tidak perlu dilakukan kultur darah ulang. Pemberian nutrisi parenteral total dengan lipid 3 gram $/ \mathrm{kgBB} /$ hari tetap diberikan selama masa perawatan.

\section{Metode penelusuran}

Prosedur pencarian literatur untuk menjawab masalah klinis tersebut dengan menelusuri pustaka secara online dengan menggunakan instrumen pencari Pubmed, Cochrane, dan Highwire. Kata kunci yang digunakan adalah "lipid", "fat", "parenteral", preterm", "premature", "low birth weight". Batasan yang digunakan adalah studi berupa uji klinis, telaah sistematik, atau meta analisis, berbahasa Inggris, dilakukan pada manusia, publikasi dalam 10 tahun terakhir. Levels of evidence (LOE) ditentukan berdasarkan klasifikasi yang dikeluarkan oleh Oxford Centre for Evidence-Based Medicine. ${ }^{13}$

\section{Hasil penelusuran literatur}

\section{Uji acak terkontrol oleh Ibrahim dkk tahun 2001 (level of evidence 2) ${ }^{14}$}

Sebuah uji kontrol teracak dilakukan terhadap 32 bayi prematur dengan usia gestasi 24-32 minggu dan berat 501-1250 gram yang membutuhkan ventilator mekanik setelah lahir serta diperkirakan tidak akan mendapat nutrisi enteral selama minimal 5-7 hari. Subjek pada kelompok intervensi $(\mathrm{n}=16)$ mendapat $3,5 \mathrm{gram} / \mathrm{kgBB} / \mathrm{hari}$ asam amino dan 3 gram $/ \mathrm{kgBB} /$ hari lipid dalam dua jam setelah kelahiran. Subjek pada kelompok kontrol $(\mathrm{n}=16)$ mendapat 2 gram $/ \mathrm{kgBB} /$ hari asam amino dan 0,5 gram $/ \mathrm{kgBB} /$ hari lipid setelah usia $48 \mathrm{jam}$. Asam amino dan lipid dinaikkan $0,5 \mathrm{gram} / \mathrm{kgBB} / \mathrm{hari}$ hingga mencapai 3,5 gram $/ \mathrm{kgBB} /$ hari dan 3 gram $/$ $\mathrm{kgBB} /$ hari. Tidak terdapat perbedaan bermakna pada berat lahir, usia gestasi, nilai Apgar pada menit kelima, serta tingkat keparahan gangguan respirasi pada kedua kelompok. Hasil penelitian menunjukkan tidak didapatkan angka kejadian sepsis yang bermakna secara statistik pada kedua kelompok (intervensi versus kontrol $=7$ vs 6 ; p 0,73). Pada penelitian ini, diagnosis sepsis ditegakkan jika dijumpai bakteri positif dari hasil kultur darah.

2. Meta-analisis oleh Simmer dan Rao tahun 2006 (level of evidence 1$)^{8}$

Telah dijelaskan meta-analisis untuk menilai keamanan dan efikasi pemberian lipid parenteral secara dini pada bayi prematur (kurang dari 37 minggu). Definisi pemberian lipid parenteral dini jika kurang dan sama dengan lima hari setelah lahir. Sedangkan definisi sepsis jika tumbuh bakteri yang dibuktikan dari hasil kultur darah positif. Penelitian yang dimasukan dalam meta analisis ini adalah uji acak terkontrol yang didapatkan melalui penelusuran MEDLINE (1966-2004), EMBASE (1980-2004), Oxford Database of Perinatal Trials, Cochrane Central Register of Controlled Trials, CINAHL (1982-2004). Terdapat tiga uji klinis yang meneliti luaran kejadian sepsis tetapi tidak satupun penelitian yang menggunakan definisi sepsis sesuai dengan yang digunakan oleh peneliti sehingga meta-analisis tidak dapat dilakukan. Gilbertson $\mathrm{dkk}^{15}$ mendefinisikan sepsis dengan hasil kultur darah yang positif atau gambaran klinis sugestif sepsis dengan didukung hasil hematologi yang menunjukkan tanda infeksi. Pada penelitian tersebut tidak didapatkan perbedaan bermakna secara statistik untuk angka kejadian sepsis pada subjek yang diberikan lipid setelah usia 7 hari maupun subjek yang diberikan lipid dalam 24 jam pertama kelahiran (nilai proporsi 0.154 vs 0,125 ; IK95\% -0,283-0,226; p non signifikan). Sosenko $\mathrm{dkk}^{16}$ mendefinisikan sepsis dengan manifestasi klinis infeksi yang didukung dengan hasil kultur darah yang positif. Hasil penelitian menunjukkan tidak adanya perbedaan bermakna untuk kejadian sepsis pada kedua golongan grup (600-800 gram dan 800-1000 gram) yang mendapat lipid setelah usia 7 hari maupun dalam 12 jam pertama kelahiran ( $\mathrm{n}=89$ vs 82 dan 63 vs 67). Hammerman $\mathrm{dkk}^{17}$ memaparkan pada diskusi penelitiannya bahwa tidak didapatkan bukti klinis peningkatan infeksi bakteri pada subjek yang mendapat lipid sebelum maupun sesudah usia 5 hari, tetapi data berkaitan hal tersebut tidak dicantumkan. Pada ketiga penelitian ini seluruh subjek tidak mendapat diet enteral selama 7 hari dan asam amino parenteral yang diberikan tidak berbeda pada kelompok kontrol maupun intervensi. 


\section{Meta-analisis oleh Vlaardingerbroek dkk tahun 2012 (level of evidence 1)}

Meta-analisis ditujukan untuk menilai efek pemberian lipid parenteral secara dini, yaitu dalam 2 hari pertama setelah kelahiran, pada bayi dengan berat lahir sangat rendah $(<1500$ gram). Penelusuran literatur dilakukan melalui PubMed, EMBASE, dan Cochrane Central Register of Controlled Trials sampai dengan 23 Februari 2012. Terdapat tiga uji klinis yang dimasukan dalam meta-analisis, dua di antaranya studi oleh Gilbertson $\mathrm{dkk}^{15}$ dan Sosenko dkk ${ }^{16}$ juga termasuk dalam pembahasan meta-analisis sebelumnya oleh Simmer dan Rao. Uji klinis lainnya dilakukan oleh Wilson $\mathrm{dkk}^{18}$ terhadap 125 bayi dengan berat lahir sangat rendah (BBLSR) yang dirawat di ruang perawatan intensif neonatus. Perlakuan yang diberikan pada grup intervensi adalah pemberian asam amino parenteral yang dimulai saat usia 12 jam, lipid parenteral pada hari kedua, dan diet enteral pada hari pertama. Perlakuan yang diberikan pada grup kontrol adalah pemberian asam amino parenteral pada hari ketiga, lipid parenteral pada hari kelima, dan diet enteral diberikan setelah klinis stabil dan kateter arteri umbilikal dilepas. Hasil penelitian menunjukkan angka kejadian (nilai persentase 50 vs 66) serta episode terjadinya bakteremia (nilai median 0 vs 1 ) yang lebih rendah pada kelompok intervensi, tetapi tidak bermakna secara statistik. Ketiga uji klinis yang dimasukkan dalam meta analisis dinilai homogen secara statistik $\left(\operatorname{chi}^{2}=4,32 ; \mathrm{df}=3(\mathrm{p}=0,23)\right.$ dan $\left.\mathrm{I}^{2}=31 \%\right)$. Hasil penelitian menunjukkan bahwa pemberian lipid parenteral secara dini pada bayi prematur dengan BBLSR tidak meningkatkan insidens sepsis (risk ratio 0,88 ; IK 95\% 0,72-1,08; $\mathrm{p}=0,22$ ).

\section{Uji acak terkontrol oleh Vlaardingerbroek dkk tahun 2013 (level of evidence 2)}

Sebuah uji klinis kontrol teracak dilakukan terhadap 144 BBLSR untuk menilai keamanan serta efikasi pemberian lipid parenteral dini dan asam amino dosis tinggi segera setelah lahir. Subjek penelitian dilakukan stratifikasi randomisasi berdasarkan berat badan $(<1000$ gram atau 1000-1499 gram) dan jenis kelamin ke dalam tiga kelompok. Kelompok kontrol mendapat nutrisi parenteral berupa glukosa dan asam amino (2,4 gram/kgBB/hari) selama dua hari pertama kehidupan. Lipid mulai diberikan pada hari kedua kehidupan sebanyak 1,4 gram $/ \mathrm{kgBB} /$ hari dan dinaikan hingga $2,8 \mathrm{gram} / \mathrm{kgBB} / \mathrm{hari}$ pada hari selanjutnya. Kelompok kedua (lipid parenteral dini) mendapat glukosa dan asam amino sama seperti kelompok kontrol tetapi lipid diberikan segera setelah lahir, yaitu dimulai dengan dosis 2 gram $/ \mathrm{kgBB} /$ hari dan dinaikan hingga 3 gram/ $\mathrm{kgBB} /$ hari pada hari selanjutnya. Kelompok ketiga (asam amino dosis tinggi) mendapat glukosa dan lipid sama seperti kelompok kedua tetapi asam amino langsung diberikan sebesar 3,6 gram $/ \mathrm{kgBB} /$ hari segera setelah lahir.

Peneliti menilai luaran sepsis neonatorum awitan lambat (SNAL), yaitu sepsis yang terjadi setelah usia 72 jam, sebagai salah satu luaran klinis sekunder. Definisi sepsis yang digunakan adalah tumbuhnya bakteri dalam darah yang ditandai dengan minimal satu kultur darah yang positif, untuk sepsis akibat coagulase-negative staphylococci definisi yang digunakan adalah dua hasil kultur darah yang positif atau satu hasil kultur darah positif dengan didukung hasil c-reactive positive (CRP) yang meningkat. Hasil penelitian menunjukkan angka kejadian SNAL pada kelompok intervensi lebih tinggi bila dibandingkan kelompok kontrol (35\% pada kelompok II, 34\% pada kelompok III vs $17 \%$ pada kelompok I) tetapi angka tersebut tidak berbeda bermakna secara statistik (nilai $\mathrm{p}$ dan IK95\% tercantum).

\section{Pembahasan}

Lipid merupakan komponen nutrisi parenteral yang penting untuk bayi prematur karena menghasilkan energi tinggi dan menjadi satu-satunya sumber asam lemak esensial. Satu gram lipid menghasilkan energi sebesar 9 kalori, dibandingkan dengan satu gram karbohidrat atau protein yang menghasilkan energi sebesar 4 kalori. ${ }^{9,20}$ Metabolit asam lemak esensial berupa docosahexaenoic acid (DHA) dan asam arakhidonat (AA) berperan penting dalam proses organogenesis, terutama pembentukan otak dan retina, angiogenesis, dan mekanisme imunitas tubuh. ${ }^{20}$ Pemberian diet yang tidak mengandung asam lemak esensial selama 3-7 hari pada bayi prematur dapat menyebabkan terjadinya sindrom defisiensi asam lemak esensial yang ditandai dengan dermatitis, alopesia, 
trombositopenia, kerentanan terhadap infeksi bakteri berat, serta pembentukan radikal bebas, yang dapat menyebabkan terjadinya displasia bronkopulmoner dan retinopati prematuritas. ${ }^{6,20}$

Data penelitian saat ini menunjukkan bahwa pemberian nutrisi parenteral secara dini dan agresif memberikan luaran klinis yang lebih baik pada bayi prematur. ${ }^{1,25,21,22}$ European Society or Paediatric Gastroenterology, Hepatology and Nutririon (ESPGHAN) merekomendasikan pemberian lipid parenteral untuk bayi baru lahir dimulai sedapat mungkin pada hari pertama dan tidak lebih dari hari ketiga setelah lahir. ${ }^{23}$ Sampai saat ini tidak terdapat rekomendasi yang jelas mengenai dosis inisiasi pemberian lipid yang agresif, lipid dapat mulai diberikan dengan dosis 0,5-3 gram/ $\mathrm{kgBB} /$ hari dan dinaikkan secara bertahap dengan kecepatan 0,5-3 gram $/ \mathrm{kgBB} /$ hari hingga mencapai dosis maksimal 3-4 gram $/ \mathrm{kgBB} /$ hari. $^{1,2,5,6,23,24}$ Divisi Perinatologi Ilmu Kesehatan Anak FKUI-RSCM merekomendasikan pemberian lipid parenteral untuk bayi prematur dengan berat badan di bawah 2500 gram dimulai dengan 1 gram $/ \mathrm{kgBB} /$ hari dan dinaikan bertahap hingga dosis maksimal 3 gram $/ \mathrm{kgBB} /$ hari.

Pemberian lipid seringkali tidak dilakukan secara optimal karena dikhawatirkan terjadi berbagai efek samping. Penelitian terhadap 172 unit perawatan intensif neonatus di Perancis menunjukkan hanya $44 \%$ unit perawatan yang memulai pemberian lipid parenteral dalam tiga hari pertama kehidupan pada bayi prematur dengan BBLSR. ${ }^{5}$ Salah satu efek samping yang dikhawatirkan adalah meningkatkan terjadinya sepsis dan eksaserbasi kondisi infeksi yang telah ada. Pada penelitian in vitro menggunakan sel manusia didapatkan bahwa pemberian lipid mengganggu fungsi kemotaksis netrofil sehingga berpotensi menyebabkan infeksi bakteri yang berat. ${ }^{25}$ Intoleransi lipid yang ditandai dengan terjadinya hipertrigliserida dapat memengaruhi permukaan dan komposisi membran sel fagosit sehingga mengganggu fungsinya. ${ }^{26,27}$ Penelitian oleh Freeman $\mathrm{dkk}^{28}$ menunjukkan bahwa pemberian lipid parenteral berhubungan dengan terjadinya bakteremia akibat Stafilokolus koagulase-negatif, akan tetapi penggunaan kateter intravena berbahan dasar Teflon dipikirkan berkontribusi dalam hal ini.

Kasus bayi usia gestasi 28 minggu dengan berat lahir 1100 gram lahir dengan sindrom gawat napas, diberikan nutrisi parenteral total dengan lipid 1 gram/ $\mathrm{kgBB} / \mathrm{hari}$ segera setelah lahir dan dalam perawatan selanjutnya pasien mengalami perburukan klinis akibat apnu prematuritas dan infeksi. Terdapat empat penelitian yang relevan untuk menjawab pertanyaan klinis mengenai hubungan pemberian lipid parenteral secara dini dan agresif dengan kejadian sepsis neonatorum. Tidak satupun penelitian menunjukkan hasil yang signifikan secara statistik mengenai hubungan tersebut. Penelitian oleh Ibrahim $\mathrm{dkk}^{14}$ menunjukkan bahwa pemberian lipid 3 gram $/ \mathrm{kgBB} /$ hari dalam dua jam pertama setelah kelahiran tidak menunjukkan perbedaan bermakna dibandingkan dengan kelompok kontrol tetapi penelitian ini hanya melibatkan 29 subjek sehingga hasil yang tidak menunjukkan perbedaan tersebut dapat disebabkan karena kesalahan tipe 2 (beta). Penelitian meta-analisis oleh Simmer dan $\mathrm{Rao}^{7}$ tidak dapat dilakukan karena perbedaan definisi sepsis yang digunakan, tetapi masing-masing penelitian tidak menunjukkan peningkatan kejadian sepsis pada kelompok yang mendapat lipid parenteral dini. Metaanalisis oleh Vlaardingerbroek $\mathrm{dkk}^{10}$ juga menunjukkan pemberian lipid parenteral secara dini, yaitu dalam dua hari setelah kelahiran kepada bayi prematur dengan BBLSR tidak meningkatkan terjadinya sepsis. Terdapat tiga penelitian yang masuk dalam meta-analisis, dua di antaranya memasukan proven sepsis sebagai definisi operasional sepsis, sedangkan satu penelitian memasukan proven sepsis dan clinical sepsis. Intervensi yang diberikan pada penelitian Wilson $\mathrm{dkk}^{18}$ berbeda dengan dua penelitian lainnya. Pada penelitian ini perlakuan yang dibedakan tidak hanya terletak pada pemberian lipid parenteral, tetapi juga pemberian asam amino dan nutrisi enteral, namun demikian ketiga penelitian ini telah melalui uji heterogenitas dan didapatkan ketiganya homogen secara statistik. Penelitian oleh Vlaardingerbroek $\mathrm{dkk}^{19}$ menunjukkan tidak terdapat perbedaan insidens kejadian sepsis neonatorum awitan lambat (SNAL) yang bermakna secara statistik pada kelompok BBLSR yang mendapat lipid parenteraral dini dan agresif dibanding dengan kelompok kontrol, meskipun demikian perbedaan tersebut cukup bermakna secara klinis. Tiga puluh lima persen subjek pada kelompok lipid dan 34\% subjek pada kelompok lipid+asam amino dosis tinggi mengalami SNAL, sedangkan pada kelompok kontrol hanya $17 \%$ subjek yang mengalami SNAL.

Berdasarkan telaah sistematik, tidak didapatkan bukti bahwa pemberian lipid parenteral berhubungan dengan terjadinya sepsis awitan lambat pada pasien. Dosis lipid yang diberikan masih berada dalam rentang yang dipergunakan secara umum. Faktor risiko 
Angelina dkk: Pemberian lipid parenteral secara dini dan agresif pada bayi prematur: hubungannya dengan kejadian sepsis

utama SNAL adalah penggunaan alat invasif, seperti ventilator, kateter vena sentral, dan selang orogastrik, serta kebersihan tangan tenaga kesehatan yang tidak dijaga dengan baik..$^{29-31}$

Pemberian lipid parenteral pada pasien telah diusahakan sedini dan agresif, tetapi dalam perjalanan penyakitnya sempat dihentikan karena klinis sepsis yang tidak stabil. Pemberian lipid parenteral pada bayi prematur yang sedang mengalami sepsis memang masih merupakan suatu kontroversi. Dalam tiga dekade terakhir hanya dua penelitian yang meneliti hal tersebut. Hasil penelitian tetap menyarankan pemberian lipid pada bayi prematur yang mengalami sepsis hanya dosis direstriksi $1-2$ gram $/ \mathrm{kgBB} / \mathrm{hari}^{32,33}$

\section{Ringkasan}

Pemberian lipid parenteral secara dini dan agresif pada bayi prematur tidak terbukti berhubungan dengan kejadian sepsis neonatorum. Berdasarkan penelitian ilmiah yang telah dipaparkan masih terdapat variasi berkaitan dengan dosis dan waktu pemberian lipid parenteral yang dikatakan dini dan agresif. Lipid diberikan dengan dosis $0,5-3 \mathrm{gram} / \mathrm{kgBB} /$ hari segera setelah lahir sampai dengan lima hari pertama setelah kelahiran. Uji klinis dengan jumlah subjek yang besar perlu dilakukan untuk menilai hubungan pemberian lipid parenteral dini dan agresif pada bayi prematur, yaitu $3 \mathrm{gram} / \mathrm{kgBB} /$ hari segera setelah lahir, dengan kejadian sepsis neonatorum.

\section{Daftar pustaka}

1. Torrazza RM, Neu J. Evidence-based guidelines for optimization of nutrition for the very low birthweight infant. NeoReviews 2013;14:e340-9.

2. Simmer K. Aggresive nutrition for preterm infant - benefits and risks. Early Hum Dev 2007;83:631-4.

3. Gianni ML. The challenge of feeding very low birth weight infants. Ann Nutr Disord \& Ther 2014;1:1013-4.

4. Horbar JD, Ehrenkranz RA, Badger GJ. Edwards EM, Morrow $\mathrm{KA}$, Soll RF, dkk. Weight growth velocity and postnatal growth failure in infants 501 to 1500 grams: 2000-2013. Pediatrics 2015; 136:e82-92.

5. Lapillonne A, Fellous L, Mokthari M, Kermorvant-Duchemin E. Parenteral nutrition objectives for very low birth weight infants: results of a national survey. JPGN 2009;48:618-26.
6. Embleton ND, Simmer K. Practice of parenteral nutrition in VLBW and ELBW infants. Dalam: Koletzko B, Poindexter B, Uauy R, penyunting. Nutritional care of preterm infants. Munich: Karger; 2014. h.175-89.

7. Adamkin DH. Use of intravenous lipids in very lowbirthweight infants. NeoReviews. 2007;8:e543-6.

8. Simmer K, Rao SC. Early introduction of lipids to parenterallyfed preterm infants (review). Cochrane Database of Syst Rev 2005;CD005256:1-28.

9. Salama GSA, Kaabneh MAF, Almasaeed MN, Alquran MIA. Intravenous lipids for preterm infants: a review. Clin Med Insights Pediatr 2015;9:25-36.

10. Vlaardingerbroek H, Veldhorst MAB, Spronk S, van den Akker CHP, van Goudevo Parenteral lipid administration to verylow-birth-weight infants - early introduction of lipids and use of new lipid emulsions: a systematic review and meta-analysis. Am J Clin Nutr 2012;96:255-68.

11. Roeslani RD, Amir I, Nasrullah H, Suryani. Penelitian awal: faktor risiko pada sepsis neonatorum awitan dini. Sari Pediatri 2013;14:36-8.

12. Juniatiningsih A, Aminullah A, Firmasyah A. Profil mikroorganisme penyebab sepsis neonatorum di Departemen Ilmu Kesehatan Anak Rumah Sakit Cipto Mangunkusumo Jakarta. Sari Pediatri 2008;10:60-5.

13. Oxford Centre of Evidence-Based Medicine 2011 Levels of Evidence. (disitasi tanggal 2 Januari 2016). Didapat dari: http:// www.ebcm.net/index.aspx?0=5663.

14. Ibrahim HM, Jeroudi MA, Baier RJ, Dhanireddy R, Krouskop RW. Aggresive early total parental nutrition in low-birthweight infants. J Perinatol 2004;24:482-6.

15. Gilbertson N, Kovar IZ, Cox DJ, Crowe L, Palmer NT. Introduction of intravenous lipid administration on the first day of life in the very low birth weight neonate. J Pediatr 1991;119;615-23.

16. Sosenko IRS, Rodriguez-Pierce M, Bancalari E. Effect of early initiation of intravenous lipid administration on the incidence and severity of chronic lung disease in premature infants. J Pediatr 1993; 123:975-82.

17. Hammerman C, Aramburo MJ. Decreased lipid intake reduces morbidity in sick premature neonates. J Pediatr 1988;113:1083-8.

18. Wilson DC, Cairns P, Halliday HL, Reid M, McClure G, Dodge JA. Randomised controlled trial of an aggresive nutritional regimen in sick very low birthweight infants. Arch Dis Child 1997;77:F4-11.

19. Vlaardingerbroek H, Vermeulen MJ, Rock D, van der Akker CHP, Dorst K, Wattimena JL, dkk. Safety and efficacy of early parenteral lipid and high-dose amino acid administration to very low birth weight infants. J Pediatr 2013;163:638-44. 
Angelina dkk: Pemberian lipid parenteral secara dini dan agresif pada bayi prematur: hubungannya dengan kejadian sepsis

20. Martin CR. Lipids and fatty acids in the preterm infant, part 1: basic mechanism of delivery, hydrolysis, and bioavailability. Neo Reviews 2015;16:e160-8.

21. Camelo JS, Martinez FE. Nutritional dilemmas in extremely low birth weight infants and their effects on childhood, adolescence and adulthood. J Pediatr (Rio J) 2005;81:s33-42.

22. Ehrenkranz RA. Early, aggressive nutritional management for very low birth weight infants: what is the evidence. Semin Perinatol 2007;31:48-55.

23. Koletzko B, Goulet O, Hunt J, Krohn K, Shamir R. Q. Guidelines on pediatric parenteral nutrition of the European Society of Paediatric Gastroenterology, Hepatology and Nutririon (ESPGHAN) and the European Society for Clinical Nutrition and Metabolism (ESPEN), supported by European Society of Paediatric Research (ESPR). J Pediatr Gastroenterol Nutr 2005;41:s1-7.

24. Martin CR. Lipids and fatty acids in the preterm infant, part 2: clinical consideration. Neo Reviews 2015;16:e169-80.

25. Fischer GW, Wilson SR, Hunter KW, Mease AD. Diminished bacterial defences with intralipid. Lancet 1980;2:1819-20.

26. Choi YJ, Bae HJ, Lee JY, Lee HS, Kim HS, Lee HS, dkk. Analysis of risk factors for lipid intolerance of intravenous fat emulsion in very low birth weight infants. Arch Pharm Res 2015;38:914-20.

27. Wiernik A, Jarstrand C, Julander I. The effect of intralipid on mononuclear and polymorphonuclear phagocytes. Am J Clin Nutr 1983;37:256-61.

28. Freeman J, Goldmann DA, Smith NE, Sidebottom DG, Epstein MF, Platt R. Association of intravenous lipid emulsion and coagulase-negative Staphylococcal bacteremia in neonatal intensive care units. N Eng J Med 1990;323:301-8.

29. Downey LC, Smith PB, Benjamin DK. Risk factors and prevention of late onset sepsis in premature infants. Early Hum Dev 2010;86:7-12.

30. Dong Y, Speer CP. Late-onset neonatal sepsis: recent developments. Arch Dis Child Fetal Neonatal 2015;100:F257-63.

31. Bentlin MR, Rugolo LMSS, Ferrari LSL. Practices related to late-onset sepsis in very low-birth weight preterm infants. J Pediatr (Rio J) 2015;91:168-74.

32. Shouman B, Abdel-Hady H, Badr RI, Hammad E, Salam MF. Dose of intravenous lipids and rate of bacterial clearance in preterm infants with blood stream infections. Eur J Pediatr 2012;171:811-6.

33. Park W, Paust W, Schroder H. Lipid infusion in premature infants suffering from sepsis. JPEN 1986;10:627-30. 